\title{
A novel radio-sensitization method for lung cancer therapy: enhanced radiosensitization induced by antigens/antibodies reaction after targeting tumor hypoxia using Bifidobacterium
}

\section{Juan Yang ( $\sim 923338541 @ q q . c o m)$}

the Affiliated of Southwest Medical University

\section{Zhouxue Wu}

the Affiliated hospital of Southwest Medical University,Luzhou

\section{Yao Chen}

the Affiliated hospital of Southwest Medical University,Luzhou

Chuanfei Hu

the Affiliated hospital of Southwest Medical University,Luzhou

Dong Li

the Affiliated hospital of Southwest Medical University,Luzhou

Yin Liao

the Affiliated hospital of Southwest Medical University,Luzhou

Yi Li

the Affiliated hospital of Southwest Medical University,Luzhou

\section{Qinglian Wen}

the Affiliated hospital of Southwest Medical University,Luzhou

\section{Yue Chen}

the Affiliated hospital of Southwest Medical University,Luzhou

Shaozhi Fu

the Affiliated hospital of Southwest Medical University,Luzhou

Jingbo Wu

the Affiliated hospital of Southwest Medical University,Luzhou

\section{Research}

Keywords: Lung cancer, Bifidobacterium infantis, Specific antibody, radio-sensitization, Radiotherapy.

Posted Date: April 10th, 2020

DOI: https://doi.org/10.21203/rs.3.rs-22035/v1 
License: (c) (i) This work is licensed under a Creative Commons Attribution 4.0 International License. Read Full License 


\section{Abstract}

Background $₫$ The hypoxic microenvironment of solid tumors reduces the susceptibility of cancer cells to radiotherapy. Current treatments are focused on the development of anti-cancer agents that selectively target tumor cells with no toxicity to healthy tissue. Bacteria colonize and destroy tumors and have emerged as biological vectors that can survive in the tumor microenvironment.

Methods $\varangle$ In this study, a Lewis lung carcinoma transplant mouse model was established and treated with a combination of bifidobacterium infantis (Bi), its specific monoclonal antibodies $(\mathrm{Ab})$ and radiotherapy (RT). ${ }^{18}$ F-FDG PET/CT and ${ }^{18}$ F-FMISO PET/CT imaging were performed to monitor tumor growth and hypoxia in the tumor tissue. Phosphorylated histone ( $\mathrm{Y}-\mathrm{H} 2 \mathrm{AX})$, the proliferation index (Ki-67), platelet endothelial cell adhesion molecules (CD31), tumor necrosis factor-a (TNF-a), hypoxia inducible factor-1a (HIF-1a) and glucose transporter 1 (Glut-1) levels were assessed through immunohistochemistry.

Results $\bigotimes$ The results showed that the combined treatment group ( $\mathrm{Ab}+\mathrm{Bi}+\mathrm{RT})$ displayed delayed tumor growth and prolonged the survival of mice. The combined treatment group also had lower levels of HIF1a, Glut-1, and CD31 expression, and a lower uptake of FDG and FMISO. The tumors treated with the combination therapy also had lower levels of hypoxia, and increased $\mathrm{y}-\mathrm{H} 2 \mathrm{AX}$ and TNF-a expression.

Conclusion $₫ T$ Taken together, these data suggest that the combination of bifidobacterium infantis and its specific monoclonal antibodies can markedly improve the efficacy of radiotherapy for the treatment of lung cancer.

\section{Background}

Lung cancer is one of the most common malignant tumors and is a leading cause of cancer related death [1]. Non-small cell lung cancer (NSCLC) constitutes $80 \%$ of lung cancer cases in China, with a third of NSCLC patients diagnosed at locally advanced stages. Radiation therapy remains the mainstay for cancer treatment ${ }^{[2,3]}$, which despite technical advances, remains suboptimal due to radioresistance ${ }^{[4,5]}$. The effects of radiation are often transient, highlighting the need for reagents with synergistic activity ${ }^{[6-8]}$.

The efficient killing of tumor cells by radiation requires oxygen ${ }^{[9]}$. Due to the complex carcinogenic microenvironment, cancer cells develop radiation-resistance due to the various cellular hierarchies that are stimulated by hypoxia and low pH conditions ${ }^{[10,11]}$. Studies have shown that hypoxic cells are up to three times more resistant to ionizing radiation than normoxic cells ${ }^{[8,12]}$. Accordingly, hypoxic regions in solid tumors represent a cause of radiotherapy failure. Studies in patients with cervical cancer demonstrated that intratumoral oxygen tension is the most important prognostic factor for the prediction of overall survival and disease-free survival following radiation treatment ${ }^{[13]}$. These observations spurred attempts to increase intratumoral oxygenation to combine radiation with radiosensitizing agents. Although these approaches are promising, local recurrences have remained a problem, limiting gains in overall survival [14]. Anaerobic bacteria can target and destroy hypoxic regions of experimental tumors when systemically 
injected into mice ${ }^{[15]}$, suggesting that they can significantly improve the effects of radiotherapy by killing the regions of the tumors resistant to radiation therapy due to their low oxygen content ${ }^{[16]}$. Experimental studies have shown that bacteriolytic therapy with C. novyi-NT when combined with various forms of radiation therapy, results in tumor regression with relatively little toxicity in mouse models ${ }^{[17]}$. A similar approach was developed using the probiotic bifidobacterium spp., for hypoxia-selective tumor treatment in which genes that generate cytosine deaminase were transformed into $B$. infantis for delivery into melanomas ${ }^{[18]}$. This strategy used anaerobes that have been successful in clinical trials. For example, the safety of the intratumoral injection of C. novyi-NT spores (Phase1) ${ }^{[19]}$ and Phase I/II studies of APS001F, B. spp. derivatives for enzyme prodrug therapy in solid tumors have been performed [20]. Anaerobic bacteria have been shown to be effective as a bacteria-mediated strategy to deliver nanomaterials to oxygen deprived tumors ${ }^{[21]}$. Current bacteria-mediated hypoxia targeting provides an expandable spectra for therapy in cancer related disease. Specific monoclonal antibodies against bifidobacterium infantis can further alter the hypoxic state of tumor tissue. In this study, we tested this hypothesis in mice using bifidobacterium infantis, an anaerobic bacteria that is non-toxic when combined with its monoclonal antibody. These bacteria and antibodies were used in conjunction with external radiotherapy and markedly enhanced the efficacy of radiotherapy.

\section{Materials And Methods}

\section{Materials}

C57BL/6 mice (female, aged 6-8 weeks) were obtained from the Chengdu Dashuo biotechnology Co. Ltd. (Chengdu, China). All animal experiments were approved by the Institutional Animal Care and Treatment Committee of Southwest Medical University (Luzhou, China). All mice were treated humanely. Lewis lung carcinoma cell lines (LLC) were obtained from the Experimental Research Center of the Affiliated Hospital of Southwest Medical University (Luzhou, China) or from the Cell Bank of the Chinese Academy of Sciences. Cell lines were grown in RPMI-1640 (1640, Gibco, USA) supplemented with $10 \%$ fetal calf serum, $100 \mathrm{U} / \mathrm{ml}$ penicillin and $100 \mathrm{\mu g} / \mathrm{ml}$ streptomycin at $37{ }^{\circ} \mathrm{C}$ with $5 \% \mathrm{CO}_{2}$. Bifidobacterium infantis (Bi) was purchased from the Guangdong culture collection center (Guangdong, China). Specific monoclonal bifidobacterium antibodies (Ab) were prepared using AbMax Biotechnology Co., Ltd (Beijing, China). YH2AX, CD31, Ki-67, Glut-1, HIF-1a and TNF-a polyclonal antibodies were purchased from Bioworld technology Co. Ltd. (Nanjing, China).

\section{Anaerobic bacterial cultures and monoclonal antibody preparation}

Bifidobacterium infantis suspensions were grown on agar plates in an anaerobic gas bag. The bag was placed in an anaerobic tank, sealed, and incubated at a constant temperature of $37^{\circ} \mathrm{C}$. After $72 \mathrm{~h}$ colonies had formed. Anaerobic bacteria were collected and centrifuged for $10 \mathrm{~min}$ at $3000 \mathrm{rpm}$ in sterile dried test tubes, and the supernatants were discarded. Precipitates were mixed with sterile PBS, centrifuged, and suspended in sterile PBS solution. Samples were diluted from stock concentrations. Bifidobacterium 
specific monoclonal antibodies were prepared commercially (AbMax Biotechnology Co., Ltd (Beijing, China)). Antibodies were verified by immunofluorescence assays.

Collected bacterial suspensions were treated with non-specific antibodies (1:50 dilution) or (1:50 dilution) of monoclonal antibodies (Ab group) at $37^{\circ} \mathrm{C}$ for $1 \mathrm{~h}$. After washing, cells were washed in PBS three times to which $200 \mu \mathrm{l}$ of goat anti mouse IgG Cy3 fluorescent secondary antibodies (1:200 dilution) were added at $37^{\circ} \mathrm{C}$ in the dark for $1 \mathrm{~h}$. Suspensions were washed and dispersed in PBS and a small drop of each suspension was observed by fluorescence microscopy (Leica TE2000-S Microscope, Tokyo, Japan).

\section{In vivo evaluation of the anti-tumor effects}

Mice were subcutaneously injected in the right flank with $0.1 \mathrm{ml}$ of LLC cell suspension at a density of $1.0 \times 10^{6} / \mathrm{ml}$. Tumor volumes were calculated as $\times$ length $\times$ width $^{2}$. Once tumors reached an average volume of $\sim 150 \mathrm{~mm}^{3}$, tumor-bearing mice were randomly divided into the following 8 groups ( $n=12$ /group): (1) Control; (2) specific monoclonal antibody alone (Ab); (3) bifidobacterium infantis alone (Bi); (4) Bi+Ab; (5) radiotherapy alone (RT); (6) Bi+RT; (7) Ab+RT; (8) Ab+ Bi+ RT. The control group was injected with $0.2 \mathrm{ml}$ of normal saline. Mice requiring bacteria treatment were injected with $0.2 \mathrm{ml}$ of bifidobacterium infantis containing $1.0 \times 10^{7}$ colony forming units (CFU) via the tail vein $48 \mathrm{~h}$ prior to RT. Similarly, mice were injected with $0.1 \mathrm{ml}$ of $A b(0.15 \mathrm{mg} / \mathrm{ml})$ via the tail vein $0.5 \mathrm{~h}$ prior to RT. Mice were immobilized using a shielded restrainer, which allowed the tumors to be exposed whilst sparing the areas surrounding the tumor. Each tumor received irradiation at a dose of $10 \mathrm{~Gy}$. Tumors were measured every two days of treatment. Behavior, diet and other states of mice in each group were also recorded. Three mice per group were sacrificed after two days of treatment and tumor tissues were harvested for $\mathrm{Y}-\mathrm{H} 2 \mathrm{AX}$ evaluation by immunohistochemistry. Three mice per group were sacrificed after 10 days of treatment and tumor tissues were harvested for H\&E staining and immunohistochemical analysis. The remaining mice were used to observe tumor growth and survival times. All animal care and experimental procedures were performed according to our institutional Animal Care and Use guidelines.

Mice were sacrificed and the liver, heart, spleen, lungs, and kidneys of each mice were prepared for H\&E staining. To evaluate the degree of damage to normal tissue, histological changes in the organs were determined.

\section{Micro ${ }^{18}$ F-FDG and ${ }^{18}$ F-FMISO PET/CT imaging}

To investigate the early tumor response in each group, micro ${ }^{18} \mathrm{~F}-\mathrm{FDG} \mathrm{PET} / \mathrm{CT}$ imaging (Siemens, Munich, Germany) was performed. Briefly, at least three mice per group were starved for $\geq 8 \mathrm{~h}$ prior to PET/CT scans, and intravenously injected with 150-250 $\mu$ Ci FDG (0.1-0.2 ml) for at least 30 min. Mice were then administered inhalation anesthesia and placed in the center of the PET/CT imaging field. The parameters used were as follows: $80 \mathrm{kV}, 500 \mu \mathrm{A} ; 1.5 \mathrm{~mm}$ slice collimation; $10 \mathrm{~min}$ per bed position. To evaluate the oxygen content of the tumor tissue, micro ${ }^{18} \mathrm{~F}$-FMISO PET/CT imaging scans (Siemens, Munich, Germany) were performed. Similarly, at least three mice in each group were intravenously injected with 
100-150 $\mu$ Ci FMISO for $\geq 30$ min prior to scanning. Irradiation methods and specific parameters were as described for PET/CT scans.

\section{Histopathology}

Tumor tissues were obtained $48 \mathrm{~h}$ after the initial treatment for the immunohistochemical (IHC) detection of $\mathrm{y}-\mathrm{H} 2 \mathrm{AX}$. Tumor tissues from mice in each group were harvested 10 days post-treatment for other indicators of IHC ( $\mathrm{Y}-\mathrm{H} 2 \mathrm{AX}, \mathrm{Ki}-67, \mathrm{TNF}-\mathrm{a}, \mathrm{HIF-1} \mathrm{a}$ and Glut-1). Specific steps included: fixation of the tumor in neutral formaldehyde for at least $24 \mathrm{~h}$, followed by paraffin-embedding. Tissues were cut into 3-4 mm thick sections and H\&E stained. Paraffin sections were probed with anti-mouse $\mathrm{Y}-\mathrm{H} 2 \mathrm{AX}, \mathrm{Ki}-67, \mathrm{CD} 31$, TNFa, HIF-1a and Glut-1 primary antibodies. Sections were then labeled with secondary biotinylated goat antimouse antibodies as per the manufacturer's instruction (Bioworld Technology, Nanjing, China). Sections were imaged using a Leica TE2000-S microscope (Tokyo, Japan). The number of $\mathrm{y}-\mathrm{H} 2 \mathrm{AX}$, Ki-67, TNF- $\mathrm{a}$, HIF-1a and Glut-1 positive cells were calculated in five randomly selected fields (400x magnification) and are shown as the number of positive/total cells. In each tumor section, microvessel density (MVD) was calculated in five randomly selected areas (at 400x magnification) as the mean of CD31-positive microvessels.

\section{Statistical Analysis}

All statistical analysis were performed using SPSS 17.0 software (Chicago, Illinois, USA). Comparisons between the groups were performed using a Student's t-test and s one-way or two-way analysis of variance (ANOVA) for more than two groups. Survival curves were plotted using the Kaplan Meier method. Data are presented as mean \pm standard error (SE). For all tests, two-sided $p<0.05$ and $<0.01$ and $<0.001$ were considered statistically significant. All charts were designed using Prism 5.0 (GraphPad, La Jolla, CA, USA).

\section{Results}

\section{Bacterial morphology and antibody verification}

After $72 \mathrm{~h}$ of anaerobic culture (Figure $1 \mathrm{~A}$ ) the plates showed colonies with a milky white, translucent appearance, generally 1-2 mm in diameter with neat edges, which conformed to the growth characteristics of Bifidobacterium infantis (rod-shaped), (Figure 1B). Compared to the control group (bifidobacterium infantis plus non-specific antibodies), the combination of bifidobacterium infantis combination with its specific monoclonal antibody, showed red fluorescence under the fluorescence microscope (Figure 1C), indicating that the antibody is specific.

\section{Antitumor Effect in Lung cancer Mouse Model}

We next evaluated the antitumor effects of Bifidobacterium infantis and its specific monoclonal antibody in combination with RT on the growth of LLC tumors. The maximum dose of external beam radiation that could be delivered without causing morbidity was approximately $10 \mathrm{~Gy}{ }^{[17]}$. The mice showed no 
discomfort after bacteria or antibody injection. Mice in the radiotherapy group lost weight and appetite, but recovered after two days. Tumor growth curves after 16 days of treatment are shown in Figure $2 \mathrm{~A}$, The tumor volume in the $A b+B i+R T$ group was lowest $\left(754.60 \mathrm{~mm}^{3}\right)$ compared to other treatment groups $(P<0.001)$. These data suggested that the $A b+B i+R T$ group possessed a more powerful effect on delaying tumor growth. A similar effect was observed for the median survival time of mice (Figure 2B). The median survival times of the $A b+B i+R T$ group ( $49.4 \pm 5.1$ days) was significantly longer than mice treated with $\mathrm{Ab}+\mathrm{RT}$ ( $32.8 \pm 5.3$ days), $\mathrm{Bi}+\mathrm{RT}$ ( $34.5 \pm 4.7$ days), $\mathrm{RT}$ ( $31.5 \pm 3.8$ days), and other groups $(p<0.01$ in all cases). No significant differences were observed for tumor growth and survival times between treatment with RT, Ab+RT and $\mathrm{Bi}+\mathrm{RT}$ ( $p>05$ in all cases). These results suggest that $A b+B i+R T$ was effective in inhibiting tumor growth and prolonging the survival time of tumor-bearing mice. Body weight was recorded every 2 days but no significant differences were observed between groups.

\section{Micro ${ }^{18} \mathrm{~F}-\mathrm{FDG}$ and ${ }^{18} \mathrm{~F}-\mathrm{FMISO} \mathrm{PET} / \mathrm{CT}$ imaging}

The SUVmax values of ${ }^{18} \mathrm{~F}-\mathrm{FDG}$ imaging for each group were $6.12 \pm 0.15$ for control, $5.59 \pm 0.08$ for $\mathrm{Ab}$, $5.28 \pm 0.07$ for $\mathrm{Bi}, 5.03 \pm 0.04$ for $\mathrm{Ab}+\mathrm{Bi}, 2.89 \pm 0.06$ for $\mathrm{Bi}+\mathrm{RT}, 3.36 \pm 0.07$ for $\mathrm{RT}$ and $3.21 \pm 0.08$ for $\mathrm{Ab}$ $+\mathrm{RT}, 1.20 \pm 0.05$ for $\mathrm{Ab}+\mathrm{Bi}+\mathrm{RT}$. Upon comparison to other groups, mice in the Ab+Bi+RT group had the lowest SUVmax, suggesting lower metabolism and a more powerful antitumor effect of $A b+B i+R T$ (P区 0.001), which was consisted in general view of the tumor xenograft model (Figure $3 \mathrm{~A}$ ). Similarly, following ${ }^{18} \mathrm{~F}-\mathrm{FMISO} \mathrm{PET} / \mathrm{CT}$ imaging (Figure 4A), the mean SUVmax of the tumors in each group were as follows: $1.28 \pm 0.10$ (control), $0.96 \pm 0.09$ (Ab), $0.86 \pm 0.05$ (Bi), $0.84 \pm 0.04$ (Ab+Bi), $0.61 \pm 0.05$ (RT), $0.51 \pm 0.04$ $(\mathrm{Bi}+\mathrm{RT}), 0.58 \pm 0.04(\mathrm{Ab}+\mathrm{RT})$ and $0.16 \pm 0.03(\mathrm{Ab}+\mathrm{Bi}+\mathrm{RT})$. When compared to other groups, mice in the $\mathrm{Ab}+\mathrm{Bi}+\mathrm{RT}$ group had the lowest SUVmax, suggestive of a low oxygen content in the tumor tissue (P区 $0.001)$.

\section{IHC analysis}

The expression of $\mathrm{Y}-\mathrm{H} 2 \mathrm{AX}$ was evaluated via immunohistochemistry (Figure 5A). The effects of deoxyribonucleic acid (DNA) damage in experimental groups was determined through the assessment of the expression of tumor-associated $\mathrm{Y}-\mathrm{H} 2 \mathrm{AX}$. When compared to other groups, an increased number of $\mathrm{Y}^{-}$ $\mathrm{H} 2 \mathrm{AX}$ positive cells were observed in the tumor tissue derived from mice treated with $\mathrm{Ab}+\mathrm{Bi}+\mathrm{RT}$ (Figure $5 B)$. Quantitative analysis of $\mathrm{Y}-\mathrm{H} 2 \mathrm{AX}$ positive cells in the different treatment groups indicated the following order: $\mathrm{Ab}+\mathrm{Bi}+\mathrm{RT}>\mathrm{Bi}+\mathrm{RT}>\mathrm{Ab}+\mathrm{RT}>\mathrm{RT}>\mathrm{Ab}+\mathrm{Bi}>\mathrm{Bi}>\mathrm{Ab}>$ Control. The number of $\mathrm{y}-\mathrm{H} 2 \mathrm{AX}$ positive cells in the tumor tissue derived from $\mathrm{Bi}+\mathrm{RT}$-treated mice $(49.80 \% \pm 2.37 \%)$ was higher than other groups except for the combination treatment group ( $\mathrm{P} \otimes 0.05$ in all cases). The number of $\mathrm{Y}-\mathrm{H} 2 \mathrm{AX}$ positive cells in the tumor tissue derived from $\mathrm{Ab}+\mathrm{Bi}+\mathrm{RT}$-treated mice $(85.22 \% \pm 3.60 \%)$ was significantly higher than $\mathrm{Bi}+\mathrm{RT}$-treated mice $(49.80 \% \pm 2.37 \%)$ and mice in the other treatment groups (Pख0.01 in all cases). These results indicated that the combination treatment of $A b+B i$ and $R T$ significantly increased the number of DNA double-strand breakages. 
The proliferation of tumor cells was assessed via Ki-67 assays. As shown in Figure $5 \mathrm{C}$, the number of $\mathrm{Ki}-$ 67 positive cells in tumor tissue derived from $\mathrm{Ab}+\mathrm{Bi}+\mathrm{RT}$-treated mice $(15.94 \% \pm 2.48 \%)$ was significantly lower than that of control-treated mice $(86.12 \% \pm 3.59 \%)$, RT-treated mice $(43.87 \% \pm 3.54 \%)$, Bi+ RT-treated mice $(38.43 \% \pm 4.82 \%), A b+R T(41.05 \% \pm 4.48 \%)$ and mice in the other treatment groups (P区0.01 in all cases). No significant differences were observed between mice in RT, Bi +RT and Ab +RT groups ( $p>05$ in all cases), indicating that the combination treatment significantly inhibited the proliferation of tumor cells.

The expression of CD31, an endothelial cell surface molecule that can be used to investigate MVD, was

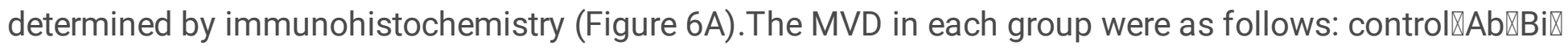
$A b+B i \otimes R T \triangle A b+R T \otimes B i+R T \triangle A b+B i+R T$ (Figure 6B). The MVD of the tumor tissue derived from mice in the $A b+B i+R T$ group $(0.67 \pm 0.57)$ was significantly lower than mice in the $B i+R T$ group $(3.48 \pm 0.87)$ and other groups (Pख0.01 in all cases). The MVD was also significantly lower in the Ab+ Bi + RT group.

The expression of TNF-a, a marker of apoptosis, was determined by immunohistochemistry (Figure 6A). As shown in Figure $6 \mathrm{C}$, the $\mathrm{Ab}+\mathrm{Bi}+\mathrm{RT}$ group had significantly increased apoptotic rates $(81.60 \% \pm 3.15 \%)$ compared to the control group $(3.74 \% \pm 1.12 \%)$, Bi+ RT group $(42.14 \% \pm 3.13 \%)$ and other groups (Pख0.001 in all cases). These data indicated that $\mathrm{AB}+\mathrm{Bi}$ dramatically enhanced radiation-induced cellular killing effects when combined with RT.

Glut-1 is an endogenous marker of hypoxia as was assessed via immunohistochemistry (Figure 7A). The percentage of Glut-1 positive cells differed across the different treatment groups in the order: $\mathrm{Ab}+\mathrm{Bi}+\mathrm{RT}<$ $\mathrm{Bi}+\mathrm{RT}<\mathrm{Ab}+\mathrm{RT}<\mathrm{RT}<\mathrm{Ab}+\mathrm{Bi}<\mathrm{Bi}<\mathrm{Ab}<$ Control (Figure 7B). A reduction in the number of Glut-1 positive cells was observed in tumor tissues derived from mice in the $A b+B i+R T$ group $(13.20 \% \pm 3.34 \%)$ compared to mice in the RT group (53.32\% $\pm 2.35 \%), A b+R T$ group $(51.63 \% \pm 2.97 \%), \mathrm{Bi}+\mathrm{RT}(45.32 \% \pm$ $2.76 \%$ ) and other groups ( $p<.0001$ in all cases). Taken together, these data show that the combination treatment of $A b+B i+R T$ significantly improves the oxygen content of tumor tissue.

The expression of HIF-1a was evaluated via immunohistochemistry (Figure 7A). As shown in Figure 7C, the percentage of HIF-1 a positive cells in the tumor tissue derived from Ab+ Bi+ RT-treated mice $(16.49 \%$ $\pm 2.42 \%$ ) was significantly lower than that of the RT-treated mice $(37.67 \% \pm 2.54 \%)$, Bi+ RT-treated mice (32.34\% $\pm 3.82 \%), A b+R T(36.05 \% \pm 4.01 \%)$ and mice in the other treatment groups (Pख0.01 in all cases). In addition, the percentage of HIF-1a positive cells in the Bi+ RT group was lower compared to the RT group, $\mathrm{Ab}+\mathrm{RT}$ group and other groups ( $\mathrm{p} \otimes 0.05$ in all cases), indicating that the combination treatment significantly improved the oxygen content of the tumor tissue and inhibited the proliferation of tumor cells.

\section{In vivo side effects}

We investigated the side effects of $A b$ or Bi to investigate organ toxicity. After mice were euthanized, the heart, liver, spleen, lungs, and kidneys were dissected and prepared for H\&E staining. As shown in Figure 8, no obvious pathologic changes were observed in any of the organs. 


\section{Discussion}

Radiation therapy is one of the most broadly anti-cancer treatments acting on a wide range of tumor types ${ }^{[9]}$. The lack of oxygen in solid tumors is considered a major reason for tumor resistance to radiotherapy and chemotherapy ${ }^{[22]}$, and a driving force for malignant transformation ${ }^{[13,23]}$. Targeting hypoxia represents an effective means to improve cancer treatment. Although the hypoxia of solid tumors has lowered treatment efficacy, the hypoxic microenvironment serves as an ideal habitat for a number of anaerobic bacteria. Anaerobic bacteria have been used experimentally as anticancer agents due to their selective growth in the hypoxic/necrotic regions of solid tumors after systemic administration. Bacteria can actively migrate from the vasculature and penetrate the necrotic region of tumors. Previous studies have shown that bacteria can enhance the therapeutic effects of radiation by killing the regions of the tumors that are resistant to radiation therapy due to their low oxygen content. Bifidobacterium is an obligate anaerobic bacterium that colonizes large tumors due to their anaerobic environment. In contrast to Clostridia, bifidobacteria are non-pathogenic, non-spore-forming, and naturally found in the digestive tract of humans and other mammals. As such, live bacterial agents can enhance the treatment of tumors [24]

We established a lung cancer xenograft model in C57BL/6 mice to explore the radiation enhancement of $\mathrm{Ab}+\mathrm{Bi}$. The results described above confirmed our hypothesis that $\mathrm{Ab}+\mathrm{Bi}$ can significantly improve radiotherapy in an experimental settings. During the study, a series of observations were used to assess the therapeutic effects of RT combined with $B i$ and $A b$. Mice treated with $A b+B i+R T$ showed the highest therapeutic effects amongst the treatment groups regarding tumor volume and survival rates. This further indicated that combination therapy was more effective in a lung cancer xenograft model. The positive effects of this treatment were also assessed using ${ }^{18} \mathrm{~F}-\mathrm{FDG}$ PET/CT imaging. Several studies have shown that ${ }^{18} \mathrm{~F}$-FDG PET/CT can recognize early decreases in glucose metabolism that are associated with progression-free survival and overall survival in many cancers ${ }^{[25-27]}$. Unlike normal cells, the majority of the energy used by tumor cells relies on glycolysis, mediated by glycometabolic pathways as opposed to aerobic oxidation ${ }^{[28]}$. Thus, inhibiting proliferation can weaken glycometabolism. A higher ${ }^{18} \mathrm{~F}$-FDG uptake is indicative of a poorer therapeutic response, whilst lower uptake suggests an improved outcome. ${ }^{18}$ F-FDG PET/CT can therefore predict tumor malignancy in a clinical setting. Our data showed that the combination treatment group had the lowest levels of uptake compared to the $\mathrm{Bi}+\mathrm{RT}$ group, although ${ }^{18} \mathrm{~F}$ FDG uptake in mice in the $\mathrm{Bi}+\mathrm{RT}$ group was lower compared to that of other groups. This suggested that $\mathrm{Bi}$ in combination with RT could inhibit tumor metabolism, but when $\mathrm{Ab}+\mathrm{Bi}$ was combined with $\mathrm{RT}$, the inhibition of tumor metabolism was more significant.

${ }^{18} \mathrm{~F}$-FMISO specifically concentrates in hypoxic tissue and is used to evaluate hypoxia in experimental[29, ${ }^{30]}$ and human ${ }^{[31,32]}$ tumors using positron emission tomography (PET). Our data suggest that combination therapy leads to the lowest ${ }^{18} \mathrm{~F}$-FMISO uptake compared to other groups, indicating that the combination of $\mathrm{Bi}$ with $\mathrm{Ab}$ can improve the oxygen content and enhance the radiation effect. 
DNA is the major target of ionizing radiation that induces base damage, sugar damage, single-strand breaks (SSBs) and double-strand breaks (DSBs), of which DSBs induce histone H2AX phosphorylation, leading to cell death. Histone $\mathrm{y}-\mathrm{H} 2 \mathrm{AX}$ is an important sensor of DSBs after irradiation treatment ${ }^{[33,34]}$. In our study, the expression of $\mathrm{Y}-\mathrm{H} 2 \mathrm{AX}$ was investigated as a biomarker for DSBs. In this study, mice in the $\mathrm{Ab}+\mathrm{Bi}+\mathrm{RT}$ group had a significantly higher expression of $\mathrm{Y}-\mathrm{H} 2 \mathrm{AX}$ compared to mice in the other groups. Therefore, the radiation enhancement of $A b+B i$ was due to enhanced $X$-ray-induced DSBs.

Under regular physiological conditions, angiogenesis results in a structurally well organized and highly efficient network of vasculature. However, in tumors, angiogenesis leads to a chaotic network of blood vessels, a distinctive component of the cancer microenvironment. This vasculature can be characterized by disorganization, dilation, branching, shunts, and varied diameters that result in an inconsistent blood flow and hypoxic areas and regions of high acidity ${ }^{[35,36]}$. As previously reported, a lower MVD is related to slower tumor growth and improved biologic and clinical behavior ${ }^{[37-40]}$. Mice in the Ab+ Bi+ RT group showed the lowest expression of CD-31 and Ki-67 compared to mice in other groups. These results indicate that $\mathrm{Ab}+\mathrm{Bi}+\mathrm{RT}$ inhibited the growth of tumor cells by inhibiting tumor angiogenesis and proliferation.

Tumor necrosis factor-a (TNF-a) participates in programmed cell death. Tumor necrosis occurs as a result of endothelial cell apoptosis caused by the deactivation of integrin $a_{v} \beta_{3}$ and the disruption of the interface with the extracellular matrix (ECM), followed by T-cell activation to remove the remaining tumor cells ${ }^{[41,42]}$. Mice in the Ab+Bi+RT group showed the highest expression of TNF-a, suggesting that Ab+ $\mathrm{Bi}+\mathrm{RT}$ plays a significant role in tumor cell apoptosis. Glut-1 is the major glucose transporter in tumor cells that provides glucose for energy production ${ }^{[43]}$. Accordingly, Glut-1 expression closely correlates with tumor invasiveness and poor prognosis. Mice in the $A b+B i+R T$ group showed the lowest expression of Glut-1 compared to other groups. These results indicate that the combination treatment group inhibited the growth of tumor cells by inhibiting tumor glucose uptake with a lower availability of glucose in vivo. Hypoxia not only increases tumor aggressiveness, but causes chemoradiotherapy resistance in tumor cells, which is closely related to tumor progression ${ }^{[44,45]}$. HIF-1 a mediates the proliferation, migration, invasion and angiogenesis of tumor cells, and plays an important role in the glycometabolism of tumor tissue. The maximum uptake of 18F-FMISO correlated with the expression of HIF-1a, with mice in the Ab+ $\mathrm{Bi}+\mathrm{RT}$ group showing the lowest HIF-1a levels, indicating that the combination therapy improved the oxygen content of tumor tissue and enhanced the anti-tumor effects.

In addition, staining of the heart, liver, spleen, lung, and kidneys from each of the treatment groups was evaluated microscopically (Figure 8). Notably, no significant morphological changes in these organs were observed, indicating that the combination therapy had no obvious adverse impact on normal tissue.

Generally, when Bi was combined with RT, good radiation enhancement is observed, whilst no significant differences occurred between mice in the RT and $A b+R T$ groups. Ab+ Bi + RT showed outstanding radiation enhancement in lung cancer xenograft models. Bifidobacterium infantis targets the components of tumors least sensitive to radiation, as they are poorly oxygenated. Additionally, recent experiments 
suggested that the damage to microvascular endothelial cells is an important component of the radiation

effects ${ }^{[46]}$. Such microvascular damage would increase the niche for bifidobacterium infantis growth by creating a larger number of hypoxic areas within the tumors, thereby exacerbating bacteriolysis. When specific antibodies are combined with the bacteria implanted in the hypoxic area, radiation therapy was further Improved. Although these data are promising, some limitations should be noted. Bacteria and its specific antibodies in tumor induced apoptosis through the competition for nutrients and stimulation of the immune response. Therefore, more detailed in vivo studies on the effects of bacteria combined with its specific antibodies that target the tumor microenvironment will be further explored. Further studies on additional tumor cell lines are currently underway.

\section{Abbreviations}

Bi Bifidobacterium infantis

Ab Specific monoclonal bifidobacterium antibodies

RT radiotherapy

$\mathrm{Y}-\mathrm{H} 2 \mathrm{AX}$ Phosphorylated histone

Ki-67 the proliferation index

CD31 platelet endothelial cell adhesion molecules

TNF-a tumor necrosis factor-a

HIF-1a hypoxia inducible factor-1a

Glut-1 glucose transporter 1

\section{Declarations}

\section{Acknowledgements}

Not applicable.

\section{Funding}

This study was supported by the project from Health and Family Planning Commission of Sichuan Province (No. 17PJ557), the research project from Office of Science \& Technology and Intellectual Property of Luzhou (No. 2017), the Union Project of Luzhou and Southwest Medical University under Grant (No.14JC0144 and 2013LZLY-J40) and the open subject of Nuclear Medicine and Molecular Imaging Key Laboratory of Sichuan Province(No. 2019.282).

\section{Availability of data and materials}


All data are included in the manuscript.

\section{Authors' contributions}

JW and SF conceived the experiments. JY, ZW, YC YY and YL conducted the experiments. CH and DL analyzed and interpreted the data. JY wrote the manuscript and prepared the figures. All authors read and approved the final manuscript.

\section{Notes}

\section{Ethics approval and consent to participate}

This study was approved by the Affiliated hospital of Southwest Medical University. All animal studies were approved by Central Laboratory of Affiliated Hospital of Southwest Medical University.

\section{Consent for publication}

All authors approved of the manuscript and consented to its publication.

\section{Competing interests}

The authors declare that have no competing interests.

\section{Contributor Information}

Juan Yang, Email: 923338541@qq.com.

Zhouxue Wu, Email: 471884316@qq.com.

Yao Chen, Email: 729209045@qq.com.

Chuanfei Hu, Email: 2515759903@qq.com.

Dong Li, Email: 451576880@qq.com.

Yin Liao, Email: 1060878966@qq.com.

Yi Li, Email: 2855766432@qq.com.

Qinglian Wen, Email: wq173155@hotmail.com.

Yue Chen, Email: chenyue5523@126.com.

Shaozhi FU, Phone: +86-830-3165698, Email: shaozhifu513@163.com.

Jingbo Wu, Phone: + 86-830-3165690, Email: wjb6147@163.com. 


\section{References}

[1] Bray F, Ferlay J, Soerjomataram I, Siegel RL, Torre LA, Jemal A. Global cancer statistics 2018: GLOBOCAN estimates of incidence and mortality worldwide for 36 cancers in 185 countries. CA Cancer J Clin 2018; 68(6): 394-424.

[2] Provencio M, Sánchez A, Garrido P, Valcárcel F. New molecular targeted therapies integrated with radiation therapy in lung cancer. Clin Lung Cancer 2010; 11(2): 91-7.

[3] Crinò L, Weder W, van Meerbeeck J, Felip E, ESMO Guidelines Working Group. Early stage and locally advanced (non-metastatic) non-small-cell lung cancer: ESMO Clinical Practice Guidelines for diagnosis, treatment and follow-up. Ann Oncol 2010; 21 Suppl 5: v103-15.

[4] Hung MS, Wu YF, Chen YC. Efficacy of chemoradiotherapy versus radiation alone in patients with inoperable locally advanced non-small-cell lung cancer: A meta-analysis and systematic review. Medicine (Baltimore) 2019; 98(27): e16167.

[5] Machtay M, Paulus R, Moughan J, Komaki R, Bradley JE, Choy H, et al. Defining local-regional control and its importance in locally advanced non-small cell lung carcinoma. J Thorac Oncol 2012; 7(4): 716-22.

[6] Chmura SJ, Gupta N, Advani SJ, Kufe DW, Weichselbaum RR. Prospects for viral-based strategies enhancing the anti-tumor effects of ionizing radiation. Semin Radiat Oncol 2001; 11(4): 338-45.

[7] McGinn CJ, Lawrence TS. Recent advances in the use of radiosensitizing nucleosides. Semin Radiat Oncol 2001; 11(4): 270-80.

[8] Wachsberger P, Burd R, Dicker AP. Tumor response to ionizing radiation combined with antiangiogenesis or vascular targeting agents: exploring mechanisms of interaction. Clin Cancer Res 2003; 9(6): 1957-71.

[9] Harrison LB, Chadha M, Hill RJ, Hu K, Shasha D. Impact of tumor hypoxia and anemia on radiation therapy outcomes. Oncologist 2002; 7(6): 492-508.

[10] Brown JM, Wilson WR. Exploiting tumour hypoxia in cancer treatment. Nat Rev Cancer 2004; 4(6): 437-47.

[11] Xia Y, Choi HK, Lee K. Recent advances in hypoxia-inducible factor (HIF)-1 inhibitors. Eur J Med Chem 2012; 49: 24-40.

[12] Teicher BA. Physiologic mechanisms of therapeutic resistance. Blood flow and hypoxia. Hematol Oncol Clin North Am 1995; 9(2): 475-506. 
[13] Hockel M, Schlenger K, Aral B, Mitze M, Schaffer U, Vaupel P. Association between tumor hypoxia and malignant progression in advanced cancer of the uterine cervix. Cancer Res 1996; 56(19): 4509-15.

[14] Dueñas-Gonzalez A, Cetina L, Mariscal I, de la Garza J. Modern management of locally advanced cervical carcinoma. Cancer Treat Rev 2003; 29(5): 389-99.

[15] Sznol M, Lin SL, Bermudes D, Zheng LM, King I. Use of preferentially replicating bacteria for the treatment of cancer. J Clin Invest 2000; 105(8): 1027-30.

[16] Dang LH, Bettegowda C, Huso DL, Kinzler KW, Vogelstein B. Combination bacteriolytic therapy for the treatment of experimental tumors. Proc Natl Acad Sci U S A 2001; 98(26): 15155-60.

[17] Bettegowda C, Dang LH, Abrams R, Huso DL, Dillehay L, Cheong I, et al. Overcoming the hypoxic barrier to radiation therapy with anaerobic bacteria. Proc Natl Acad Sci U S A 2003; 100(25): 15083-8.

[18] Yi C, Huang Y, Guo ZY, Wang SR. Antitumor effect of cytosine deaminase/5-fluorocytosine suicide gene therapy system mediated by Bifidobacterium infantis on melanoma. Acta Pharmacol Sin 2005; 26(5): 629-34.

[19] Roberts NJ, Zhang L, Janku F, Collins A, Bai RY, Staedtke V, et al. Intratumoral injection of Clostridium novyi-NT spores induces antitumor responses. Sci Transl Med 2014; 6(249): 249ra111.

[20] Phase I/II study of APS001F with flucytosine and maltose in solid tumors (ClinicalTrials.gov Identifier: NCT01562626, last verified: December 2014; https://clinicaltrials.gov/ct2/show/NCT01562626).

[21] Luo CH, Huang CT, Su CH, Yeh CS. Bacteria-Mediated Hypoxia-Specific Delivery of Nanoparticles for Tumors Imaging and Therapy. Nano Lett 2016; 16(6): 3493-9.

[22] Bristow RG, Hill RP. Hypoxia and metabolism. Hypoxia, DNA repair and genetic instability. Nat Rev Cancer 2008; 8(3): 180-92.

[23] Vaupel P. Hypoxia and aggressive tumor phenotype: implications for therapy and prognosis. Oncologist 2008; 13 Suppl 3: 21-6.

[24] Yazawa K, Fujimori M, Nakamura T, Sasaki T, Amano J, Kano Y, et al. Bifidobacterium longum as a delivery system for gene therapy of chemically induced rat mammary tumors. Breast Cancer Res Treat 2001; 66(2): 165-70.

[25] Ni XL, Chen LX, Zhang $H$, Yang B, Xu S, Wu M, et al. In vitro and in vivo antitumor effect of gefitinib nanoparticles on human lung cancer. Drug Deliv 2017; 24(1): 1501-1512.

[26] Yu Y, Xu S, You H, Zhang Y, Yang B, Sun X, et al. In vivo synergistic anti-tumor effect of paclitaxel nanoparticles combined with radiotherapy on human cervical carcinoma. Drug Deliv 2017; 24(1): 75-82. 
[27] Van den Abbeele AD. The lessons of GIST--PET and PET/CT: a new paradigm for imaging. Oncologist 2008; 13 Suppl 2: 8-13.

[28] Xu XD, Shao SX, Jiang HP, Cao YW, Wang YH, Yang XC, et al. Warburg effect or reverse Warburg effect? A review of cancer metabolism. Oncol Res Treat 2015; 38(3): 117-22.

[29] Kubota K, Tada M, Yamada S, Hori K, Saito S, Iwata R, et al. Comparison of the distribution of fluorine-18 fluoromisonidazole, deoxyglucose and methionine in tumour tissue. Eur J Nucl Med 1999; 26(7): 750-7.

[30] Rasey JS, Casciari JJ, Hofstrand PD, Muzi M, Graham MM, Chin LK. Determining hypoxic fraction in a rat glioma by uptake of radiolabeled fluoromisonidazole. Radiat Res 2000; 153(1): 84-92.

[31] Koh WJ, Rasey JS, Evans ML, Grierson JR, Lewellen TK, Graham MM, et al. Imaging of hypoxia in human tumors with [F-18]fluoromisonidazole. Int J Radiat Oncol Biol Phys 1992; 22(1): 199-212.

[32] Valk PE, Mathis CA, Prados MD, Gilbert JC, Budinger TF. Hypoxia in human gliomas: demonstration by PET with fluorine-18-fluoromisonidazole. J Nucl Med 1992; 33(12): 2133-7.

[33] Jiang Y, Allen D, Kersemans V, Devery AM, Bokobza SM, Smart S, et al. Acute vascular response to cediranib treatment in human non-small-cell lung cancer xenografts with different tumour stromal architecture. Lung Cancer 2015; 90(2): 191-8.

[34] Mah LJ, El-Osta A, Karagiannis TC. gammaH2AX: a sensitive molecular marker of DNA damage and repair. Leukemia 2010; 24(4): 679-86.

[35] Carmeliet P, Jain RK. Angiogenesis in cancer and other diseases. Nature 2000; 407(6801): 249-57.

[36] Helmlinger G, Yuan F, Dellian M, Jain RK. Interstitial pH and pO2 gradients in solid tumors in vivo: high-resolution measurements reveal a lack of correlation. Nat Med 1997; 3(2): 177-82.

[37] Glatzel-Plucinska N, Piotrowska A, Grzegrzolka J, Olbromski M, Rzechonek A, Dziegiel P, et al. SATB1 Level Correlates with Ki-67 Expression and Is a Positive Prognostic Factor in Non-small Cell Lung Carcinoma. Anticancer Res 2018; 38(2): 723-736.

[38] Xie F, Ding RL, He WF, Liu ZJ, Fu SZ, Wu JB, et al. In vivo antitumor effect of endostatin-loaded chitosan nanoparticles combined with paclitaxel on Lewis lung carcinoma. Drug Deliv 2017; 24(1): 14101418.

[39] Sun CJ, Yang ZG, Zhou XP, Zhou QH, Sun JT, Zhang SF, et al. Non-small cell lung cancer evaluated by first pass dynamic contrast-enhanced 16-slice spiral CT: correlation of tumor vascularity with pathological characteristics. Zhonghua Zhong Liu Za Zhi 2007; 29(6): 429-33. 
[40] Ranjan AP, Mukerjee A, Gdowski A, Helson L, Bouchard A, Majeed M, et al. Curcumin-ER Prolonged Subcutaneous Delivery for the Treatment of Non-Small Cell Lung Cancer. J Biomed Nanotechnol 2016; 12(4): 679-88.

[41] Havell EA, Fiers W, North RJ. The antitumor function of tumor necrosis factor (TNF), I. Therapeutic action of TNF against an established murine sarcoma is indirect, immunologically dependent, and limited by severe toxicity. J Exp Med 1988; 167(3): 1067-85.

[42] Rüegg C, Yilmaz A, Bieler G, Bamat J, Chaubert P, Lejeune FJ. Evidence for the involvement of endothelial cell integrin alphaVbeta3 in the disruption of the tumor vasculature induced by TNF and IFNgamma. Nat Med 1998; 4(4): 408-14.

[43] Yang H, Zhong JT, Zhou SH, Han HM. Roles of GLUT-1 and HK-II expression in the biological behavior of head and neck cancer. Oncotarget 2019; 10(32): 3066-3083.

[44] Melillo G. Targeting hypoxia cell signaling for cancer therapy. Cancer Metastasis Rev 2007; 26(2): 341-52.

[45] Semenza GL. Targeting HIF-1 for cancer therapy. Nat Rev Cancer 2003; 3(10): 721-32.

[46] Garcia-Barros M, Paris F, Cordon-Cardo C, Lyden D, Rafii S, Haimovitz-Friedman A, et al. Tumor response to radiotherapy regulated by endothelial cell apoptosis. Science 2003; 300(5622): 1155-9.

\section{Figures}




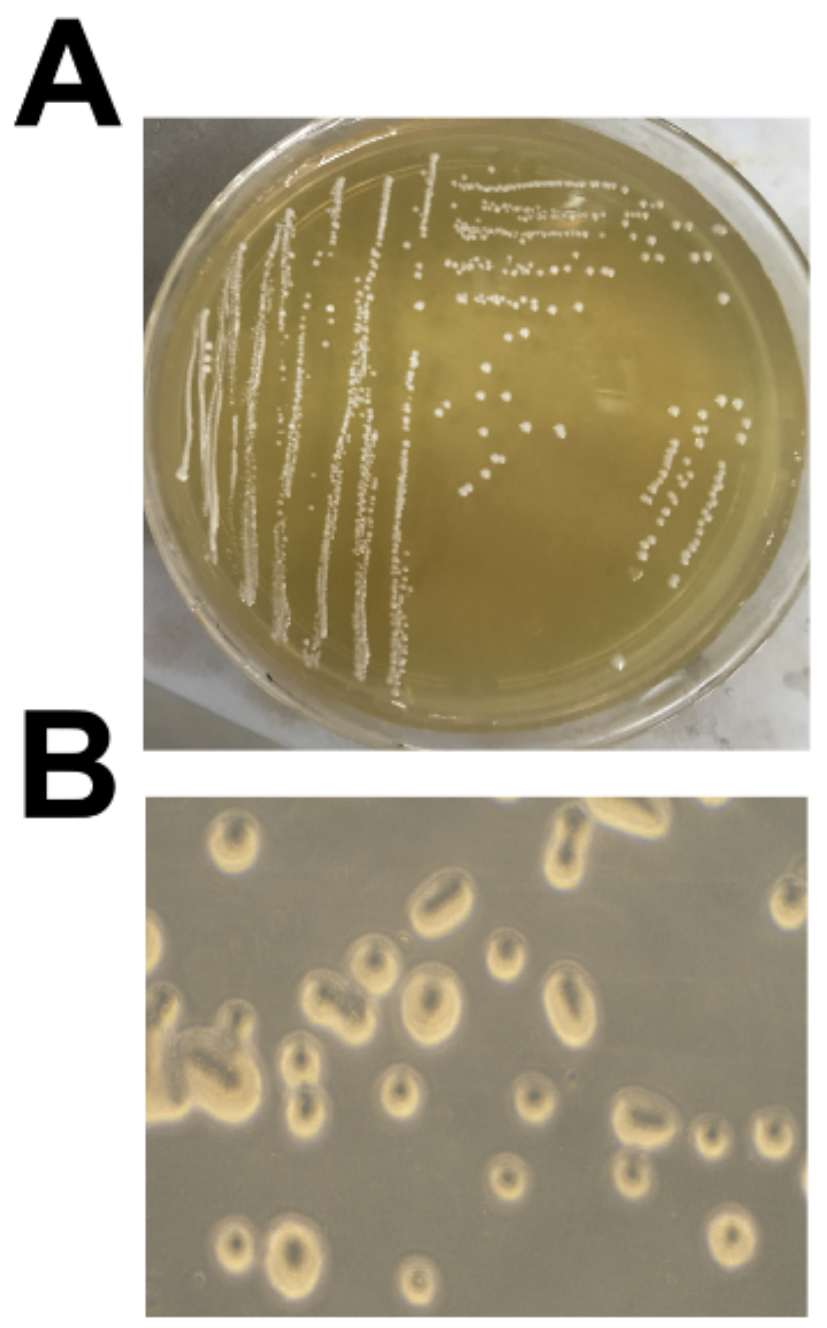

\section{Control}

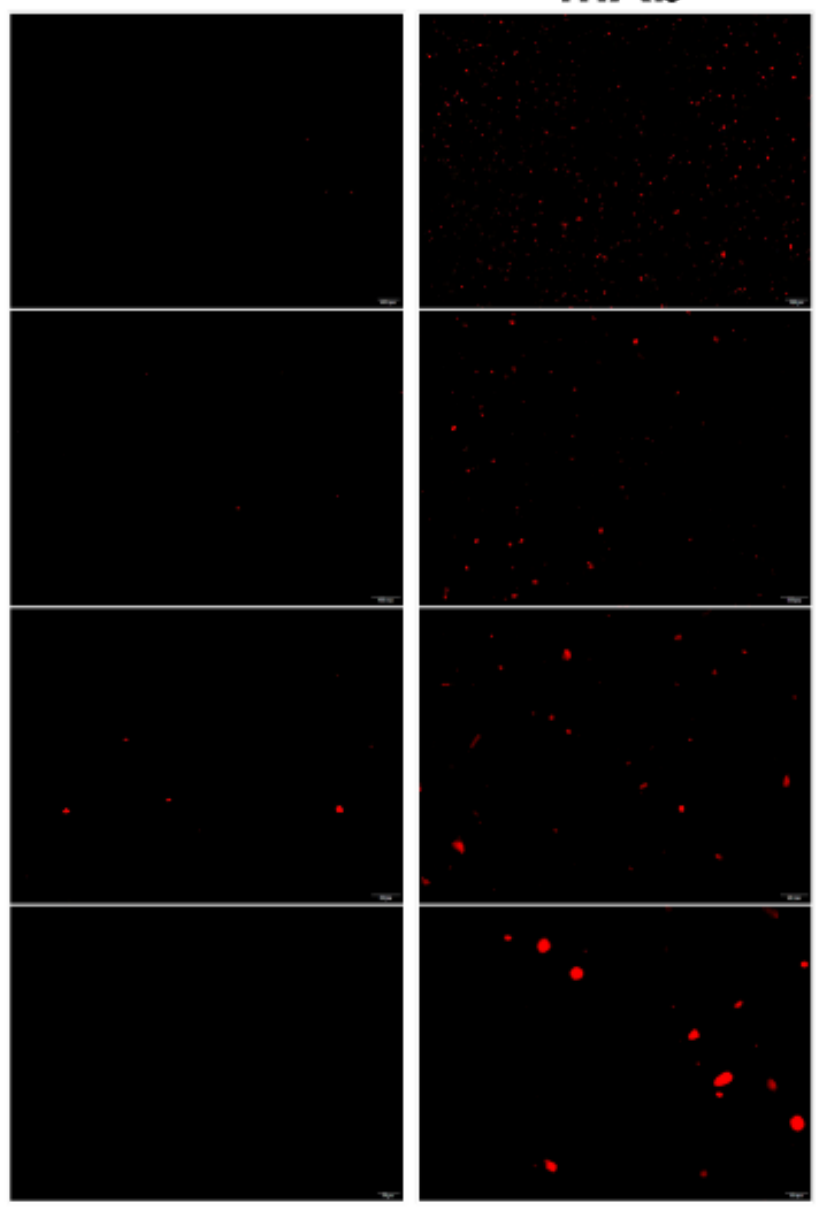

\section{Figure 1}

Morphology of Bifidobacterium infantis(A-B) and verification of antibody(C区. (A) Bi were cultured on agar plates under an anaerobic environment at $37^{\circ} \mathrm{C}$ for 48 hours, the colonies with milky white, translucent water samples, generally 1-2 mm in diameter and neat edges. (B) They are rod-shaped under the microscope (magnification, $\times 200$ ). (C) The antibody was verified by immunofluorescence assay. Bi $+A b$ showed red fluorescence under the fluorescence microscope(from top to bottom, magnification, $\times 40$, $\times 100, \times 200, \times 400)$, while Bi incubation with other antibodies showed not red fluorescence. Abbreviations: Bi: Bifidobacterium infantis; Ab: Specific monoclonal bifidobacterium antibodies. 

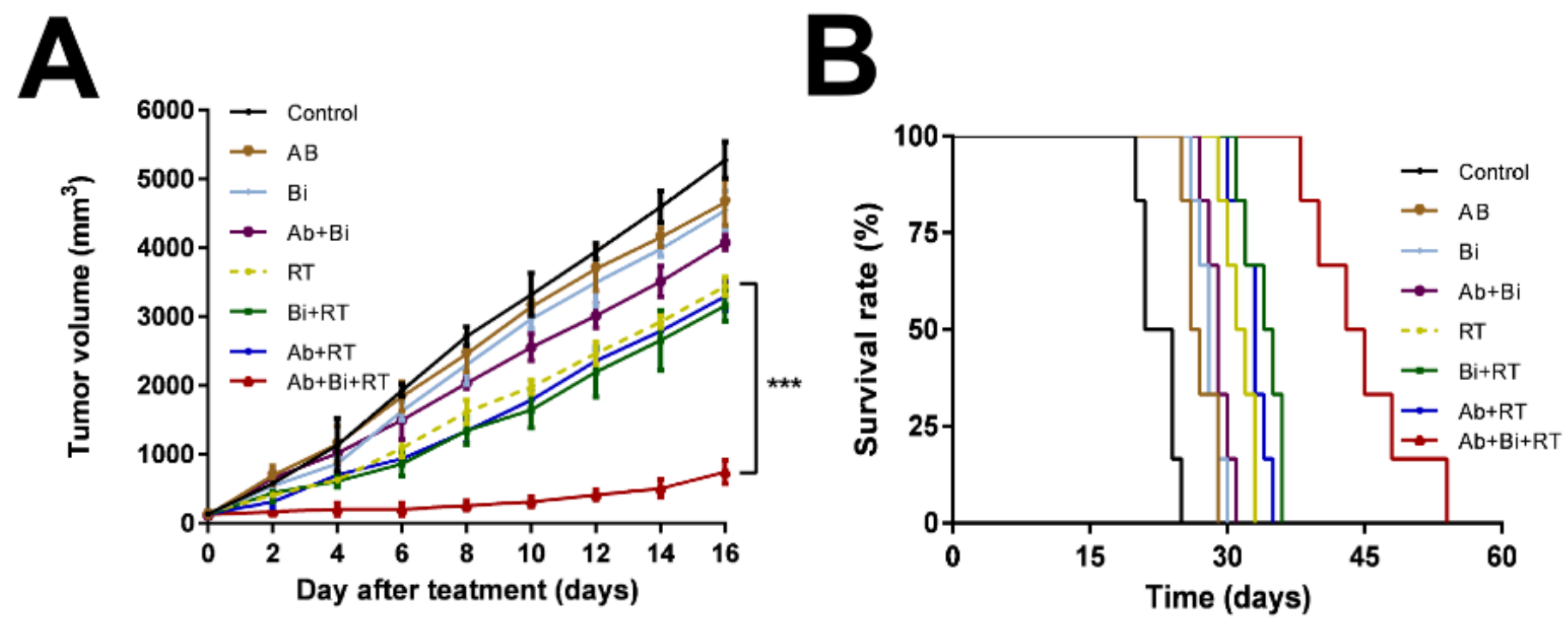

Figure 2

In vivo evaluation of the anti-tumor effects. (A) Suppression of tumor growth after different treatment regimens in C57/BL6 mice xenografted with LLC. (B) The survival rate of each group. ${ }^{\star *}{ }^{*} P<0.01$ vs all groups. Abbreviations: Bi: Bifidobacterium infantis; Ab: Specific monoclonal bifidobacterium antibodies; RT: radiotherapy.

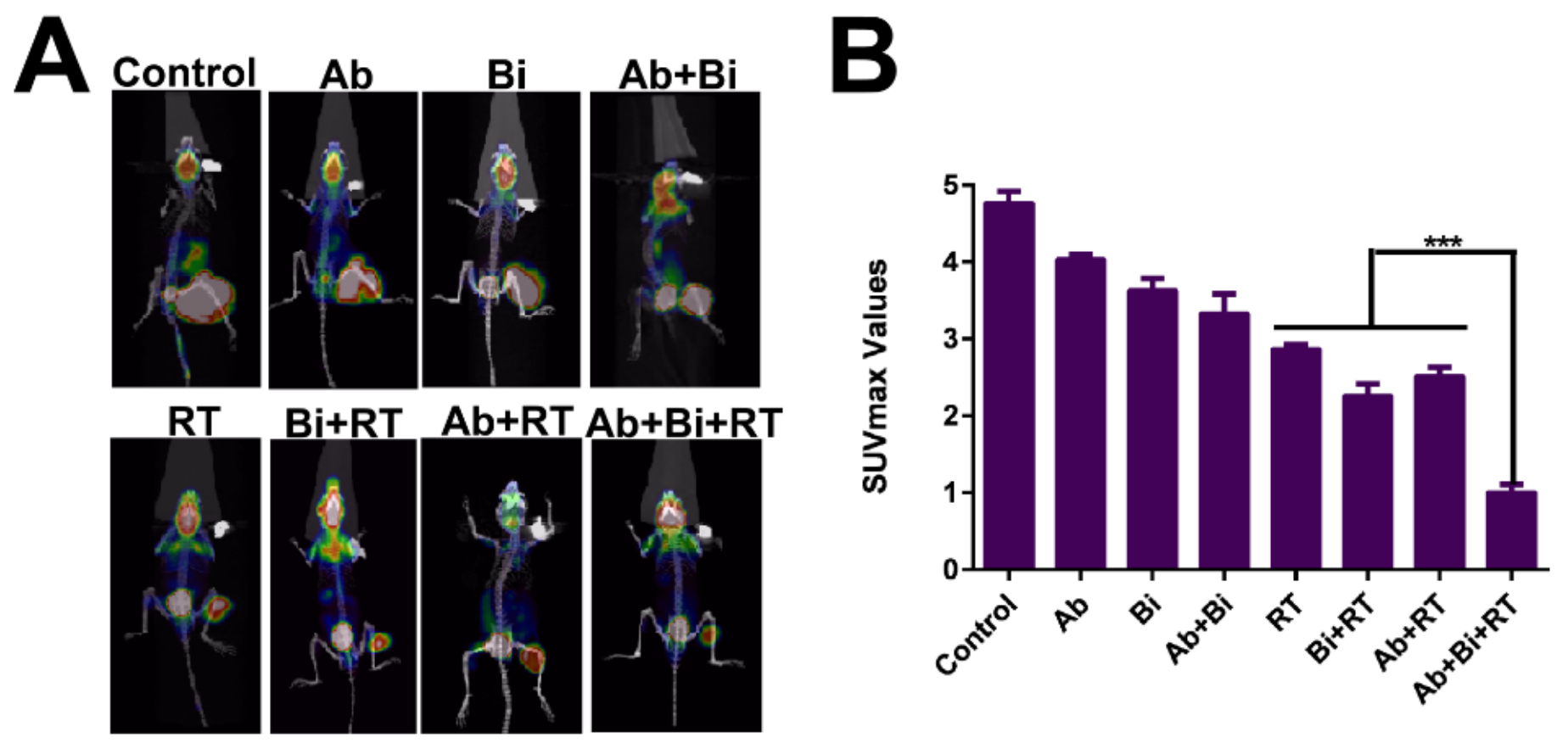

Figure 3 
Micro 18F-FDG PET/CT imaging. (A) Representative 18F-FDG PET scans of mice eight day after treatment with various regimens. (B) SUVmax associated with various treatment regimens. ${ }^{\star \star \star} P<0.001$ vs all groups. Abbreviations: Bi: Bifidobacterium infantis; Ab: Specific monoclonal bifidobacterium antibodies; RT: radiotherapy.
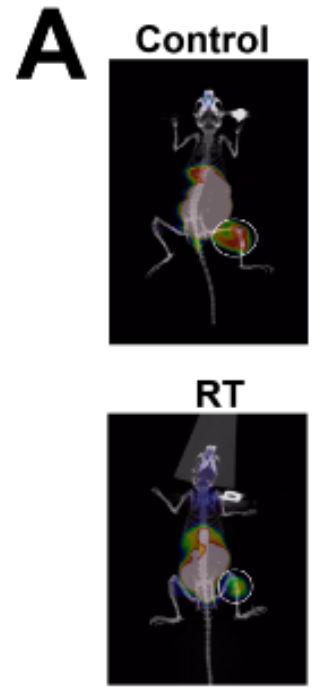

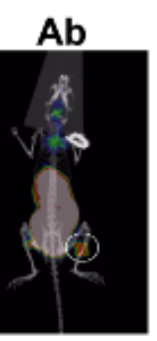

$\mathrm{Bi}+\mathbf{R T}$

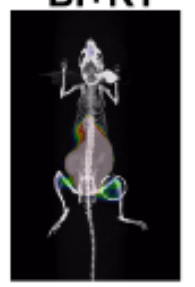

$\mathrm{Bi}$

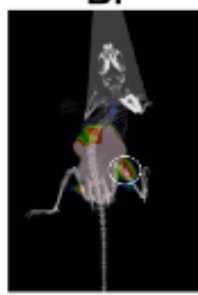

$\mathbf{A b + R T}$

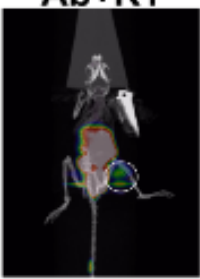

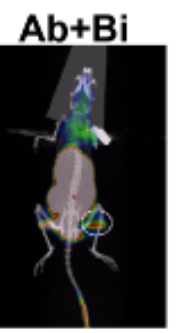

$A b+B i+R T$
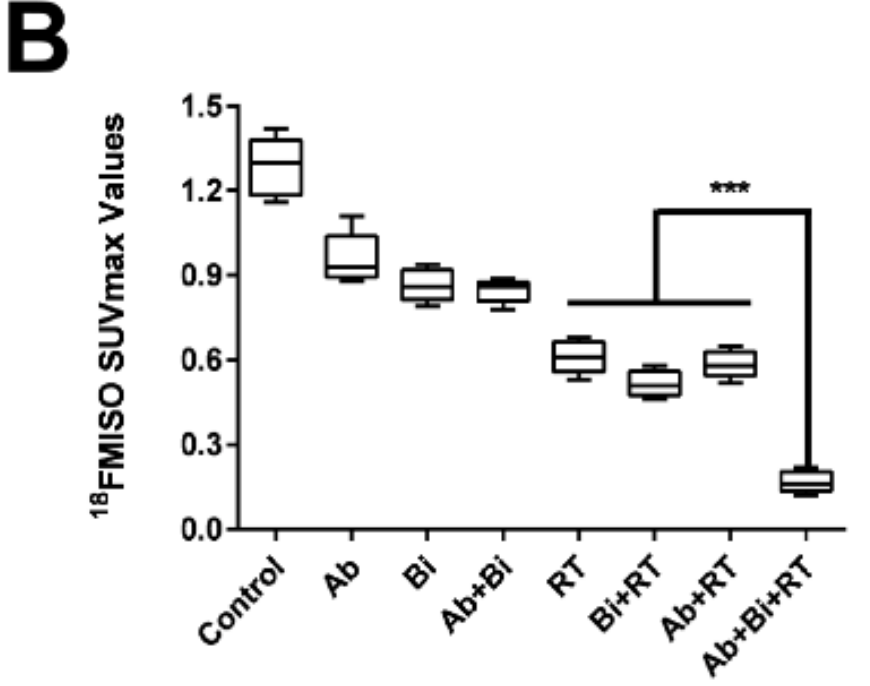

Figure 4

Micro 18F-FMISO PET/CT imaging. (A) Example mice of each group on positron emission tomography/computed tomography imaging. (B) SUVmax associated with various treatment regimens. ${ }^{\star} \star \star P<0.001$ vs all groups. Abbreviations: Bi: Bifidobacterium infantis; $A b$ : Specific monoclonal bifidobacterium antibodies; RT: radiotherapy. 


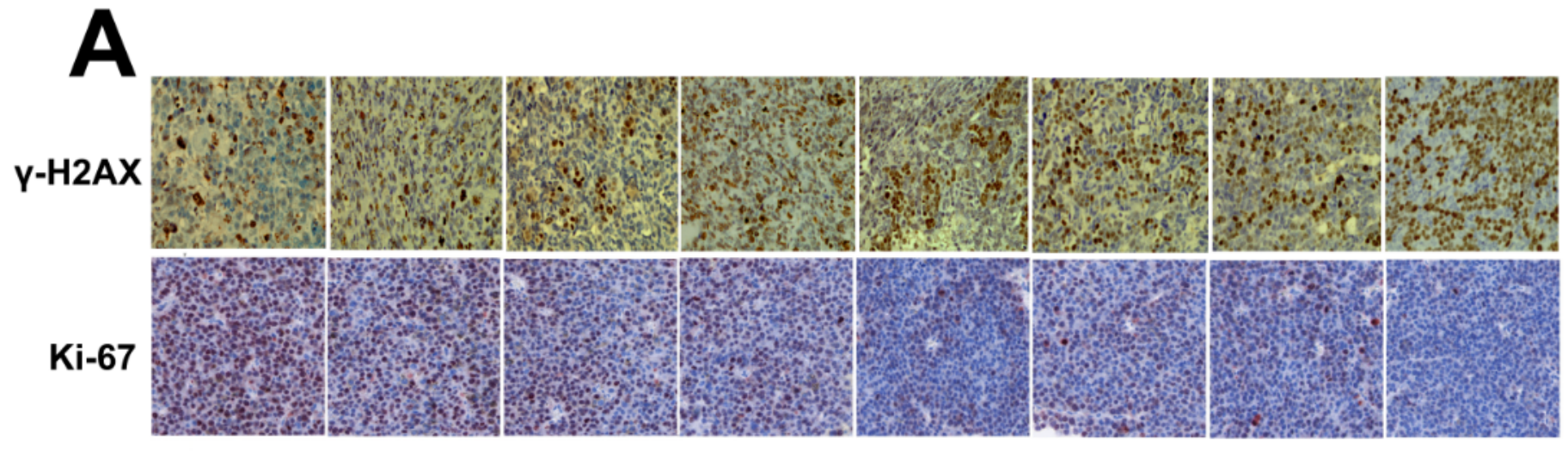

B
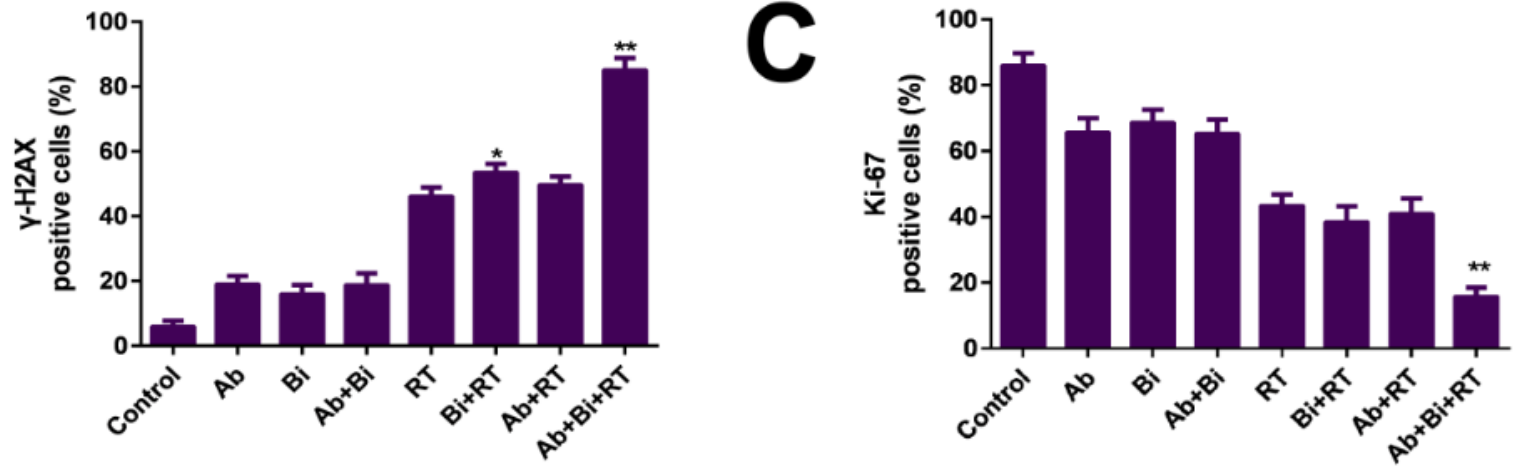

Figure 5

IHC. (A) Expression of $\mathrm{Y}-\mathrm{H} 2 \mathrm{AX}$ and $\mathrm{Ki}-67$ in Lewis tumor tissue. (magnification $\times 400$ ). (B) Quantitative analysis of $\mathrm{Y}-\mathrm{H} 2 \mathrm{AX}$. (C) Quantitative analysis of Ki-67. (Pख0.05 in all cases). ${ }^{*} \mathrm{P} \otimes 0.01$. Abbreviations: Bi: Bifidobacterium infantis; Ab: Specific monoclonal bifidobacterium antibodies; RT: radiotherapy. IHC: immunohistochemistry. 


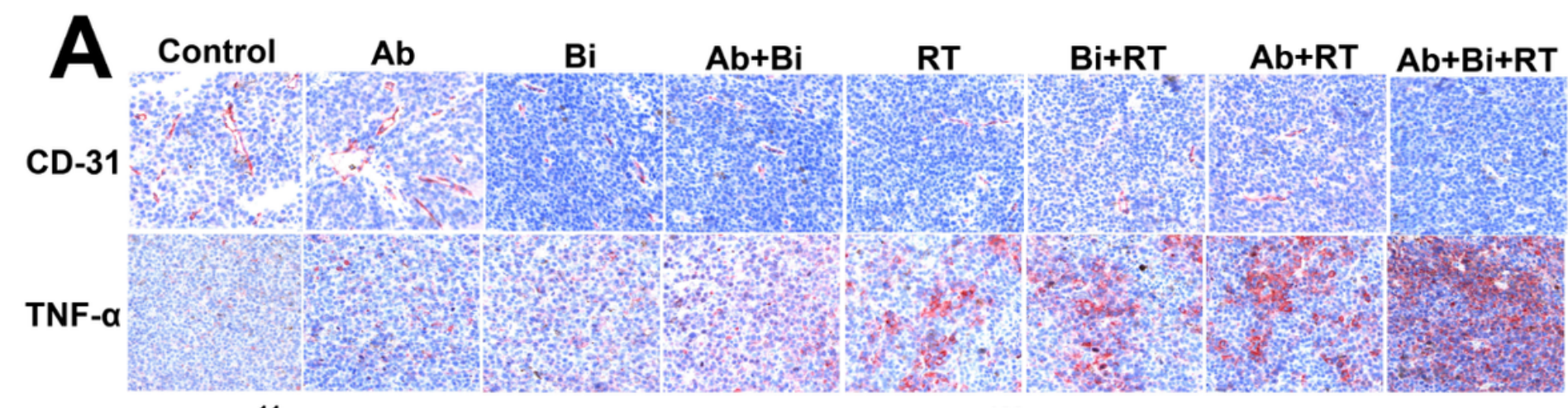

B
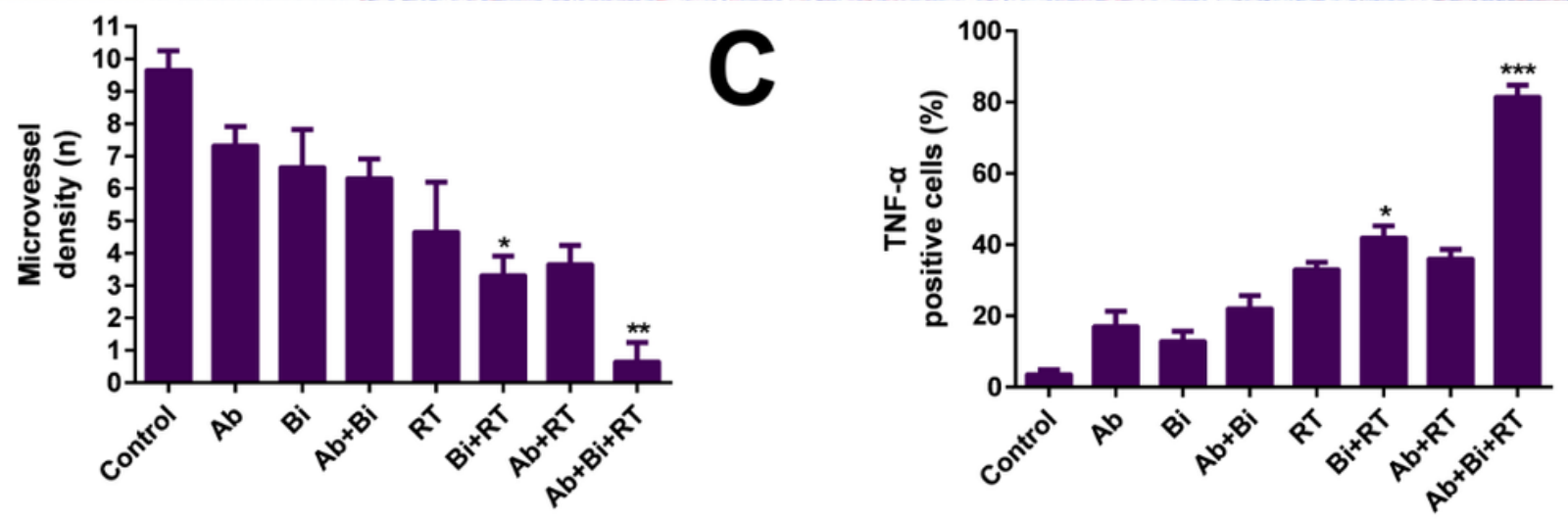

Figure 6

IHC. (A) Representative images of IHC of diverse group for the evaluation of CD-31 and TNF-a.

(magnification $\times 400$ ). (B) Quantitative analysis of CD-31. (C) Quantitative analysis of TNF-a. *P凶0.05 in all cases, ${ }^{\star *} \mathrm{P} \llbracket 0.01, * \star \star \otimes 0.001$. Abbreviations: Bi: Bifidobacterium infantis; Ab: Specific monoclonal bifidobacterium antibodies; RT: radiotherapy. IHC: immunohistochemistry. 


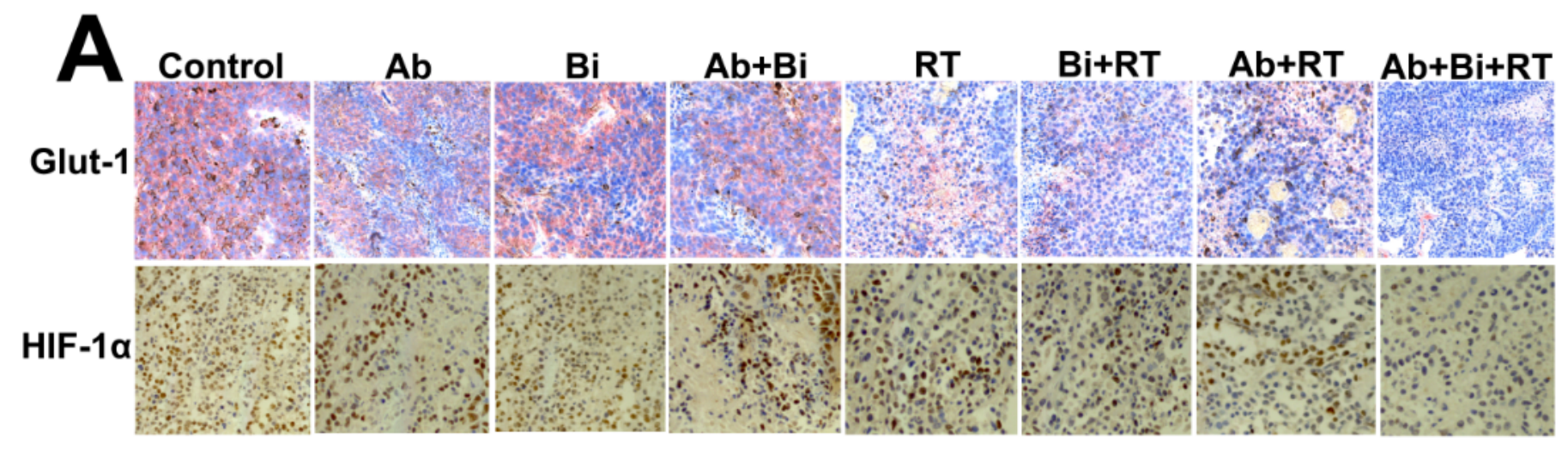

B
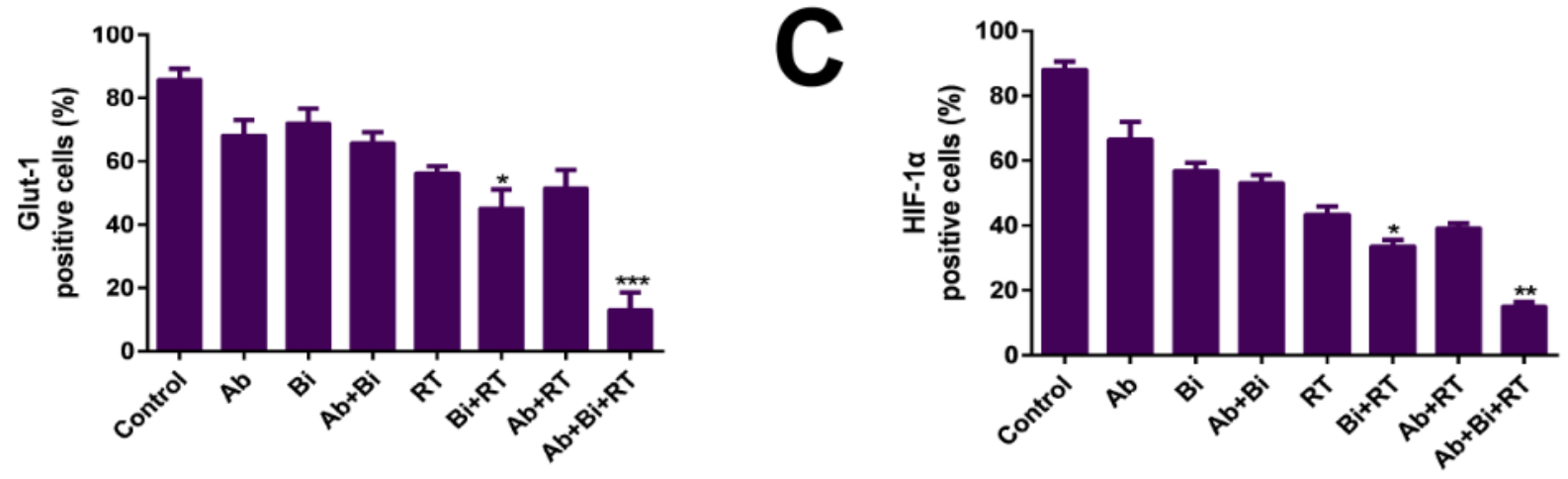

Figure 7

IHC. (A) Representative images of IHC of diverse group for the evaluation of Glut-1 and HIF-a.

(magnification ×400). (B) Quantitative analysis of Glut-1. (C) Quantitative analysis of HIF-a. *P凶0.05 in all cases, $\star \star P \otimes 0.01, * \star \star \otimes 0.001$. Abbreviations: Bi: Bifidobacterium infantis; Ab: Specific monoclonal bifidobacterium antibodies; RT: radiotherapy. IHC: immunohistochemistry.

原

Figure 8

Organs morphology of mice from different groups. Hematoxylin-eosin staining of the heart, liver, spleen, lung, kidney in different groups. (A) Control group, (B) Ab alone group, (C) Bi alone group, (D)Ab+ Bi group, (E) RT alone group, (F) Bi+ RT group, (G) Ab+ RT group, (H)Ab+ Bi +RT group. Abbreviations: $\mathrm{Bi}$ : Bifidobacterium infantis; Ab: Specific monoclonal bifidobacterium antibodies; RT: radiotherapy. 